\title{
RESISTANCE AND DIFFERENTIAL SUSCEPTIBILITY OF Bidens pilosa AND B. subalternans BIOTYPES TO ALS-INHIBITING HERBICIDES
}

Ramiro Fernando López-Ovejero ${ }^{1}$; Saul Jorge Pinto de Carvalho ${ }^{1}$; Marcelo Nicolai ${ }^{1}$; Aluana Gonçalves Abreu²; Maria Tereza Grombone-Guaratini³; Roberto Estevão Bragion Toledo ${ }^{4}$; Pedro Jacob Christoffoleti ${ }^{5 *}$

${ }^{1}$ USP/ESALQ - Programa de Pós-Graduação em Fitotecnia.

${ }^{2}$ UNICAMP - Depto. de Genética e Evolução - C.P. 6109 - 13083-970 - Campinas, SP - Brasil.

${ }_{4}^{3}$ IBt/SMA - Seção de Ecologia - C.P. 4005 - 01061-970 - São Paulo, SP - Brasil.

${ }_{5}^{4}$ Arysta LifeScience - R. Jundiai, 50 - 10 andar - 04001-904 - São Paulo, SP - Brasil.

${ }^{5}$ USP/ESALQ - Depto. de Produção Vegetal - C.P. 9 - 13418-900 - Piracicaba, SP - Brasil.

*Corresponding author <pjchrist@esalq.usp.br>

ABSTRACT: The frequent application of herbicides in agricultural areas may select resistant biotypes in weed populations, whose biological characteristics influence the speed and patterns of resistance. This research aims to charactere, simultaneously, resistance patterns and differential susceptibility of Bidens pilosa and B. subalternans biotypes to ALS-inhibiting herbicides of the imidazolinone and sulfonylurea chemical groups. Six hairy beggarticks biotypes, four suspected resistant and two known susceptible, were treated with eight rates of chlorimuron-ethyl or imazethapyr, in greenhouse conditions. Percent control and percent fresh weight of the plants were evaluated at 28 days after the application. $B$. subalternans is less susceptible to ALS-inhibiting herbicides than B. pilosa; $B$. subalternans biotypes were more resistant than $B$. pilosa biotypes; there are $B$. pilos $a$ and $B$. subalternans biotypes with cross resistance to the ALSinhibiting herbicides of the sulfonylurea and imidazolinone groups; there are different patterns of cross resistance to the diverse groups of ALS-inhibiting herbicides.

Key words: imidazolinone, sulfonylurea, hairy beggarticks, soybean

\section{RESISTÊNCIA E SUSCETIBILIDADE DIFERENCIAL DE BIÓTIPOS DE Bidens pilosa E B. subalternans AOS HERBICIDAS INIBIDORES DA ALS}

\begin{abstract}
RESUMO: A freqüente aplicação de herbicidas em áreas agrícolas pode selecionar resistência em biótipos de plantas daninhas, cujas características biológicas influenciam na velocidade e nos padrões da resistência. Este trabalho foi conduzido com o objetivo de caracterizar, simultaneamente, o padrão de resistência e a susceptibilidade diferencial de biótipos de Bidens pilosa e B. subalternans aos herbicidas inibidores da ALS dos grupos químicos das imidazolinonas e sulfoniluréias. Para tanto, seis biótipos de picão-preto, quatro supostamente resistentes e dois sabidamente suscetíveis, foram submetidos à aplicação de oito doses de chlorimoron-ethyl ou imazethapyr, em condição de casa-de-vegetação. Avaliou-se o controle e a massa fresca percentual das plantas aos 28 dias após a aplicação. B. subalternans é menos suscetível aos herbicidas inibidores da ALS que $B$. pilosa; os biótipos de $B$. subalternans mostraram-se mais resistentes que o biótipo de $B$. pilosa; há ocorrência de biótipos de $B$. pilosa e $B$. subalternans com resistência cruzada aos herbicidas inibidores da ALS do grupo das sulfoniluréias e imidazolinonas; há padrões diferenciados de resistência cruzada de picão-preto aos diversos grupos de herbicidas inibidores da ALS.
\end{abstract}

Palavras-chave: imidazolinona, sulfoniluréia, picão-preto, soja

\section{INTRODUCTION}

Acetolactate synthase (ALS)-inhibiting herbicides are among the most effective and widely used herbicides (Tranel \& Wright, 2002), and the selection of resistant biotypes by these products (imidazolinones - IMIs, sulfonylurea - SUL, triazolopyrimidine sulfonanilides - TPs and pyrimidinylthiobenzoates PTBs) has been observed in many parts of the world (Heap, 2005; http//:www.weedscience.com).

Weed resistance to herbicides is defined as a natural and inherited capacity of biotypes to survive and reproduce after the application of an herbicide rate that should be lethal to a normal (susceptible) popula- 
tion of the same species (Christoffoleti \& LópezOvejero, 2004). The two most notable weeds that have gained resistance to ALS-inhibiting herbicides in Brazilian soybean fields are Bidens pilosa and $B$. subalternans (Christoffoleti, 2002; Gelmini et al., 2002).

Morphology and the ecological conditions of habitats occupied by both B. pilosa and B. subalternans are quite similar; these are sympathric species infesting soybean fields (Kissmann \& Groth, 1999). Their similarity and overlapping of characters have resulted in imprecise taxonomic characterization, difficulty in establishing clear boundaries, and doubts about the material identification (Grombone-Guaratini et al., 2005a; 2005b), even in resistance experiments. These weed species are difficult to control mainly because of their high levels of inbreeding and seed production, and long term survival of seeds on the soil (GromboneGuaratini et al., 2004).

However, because it is so difficult identify Bidens species accurately, many authors could not say with which species they to dealt with (Monquero et al., 2000; Carvalho et al., 2004). This fact raises questions about the populations used in several published works. The aims of this research were (i) identify and characterize ALS-resistant Bidens biotypes, and (ii) evaluate the degree of resistance and differential susceptibility of B. pilosa and B. subalternans biotypes to chlorimuron-ethyl and imazethapyr.

\section{MATERIAL AND METHODS}

Seed origin - Seeds from resistant biotypes of Bidens pilosa and $B$. subalternans were collected from soybean production areas in São Paulo (SP), Paraná (PR), Mato Grosso (MT), and Mato Grosso do Sul (MS) states, on properties that had been sprayed with ALS-inhibiting herbicides for at least six consecutive years. Susceptible seed samples were collected in the open field in Santa Bárbara do Oeste (SP) and Instituto de Botânica de São Paulo (IBt/SMA), which had never been sprayed with ALS-inhibiting herbicides. For locations and biotype names see Table 1 .

\section{Dose-response curves}

Place - The experiment was conducted in a greenhouse at Piracicaba - SP, Brazil (22 $41^{\prime} 15^{\prime}$ 'S, $47^{\circ} 41^{\prime} 15^{\prime \prime} \mathrm{W}$ and $560 \mathrm{~m}$ of altitude) from December/ 2004 to February/2005.

Bioassay testing ALS sensitivity to herbicides - Seeds were germinated in plastic boxes $(0.11 \times 0.11$ $\times 0.03 \mathrm{~m}$ ) filled with commercial substrate, inside a germination chamber with photoperiod $8 \mathrm{~h}$-light, $30^{\circ} \mathrm{C}$, and $16 \mathrm{~h}$-dark, $20^{\circ} \mathrm{C}$. When seedlings were at the cotyledon stage, they were transplanted to 0.5 -L plastic pots (four plants per pot), also filled with commercial substrate.

When plants averaged, four leaves, post-emergence herbicide treatments were applied. Spraying was done inside closed spray chamber, using a flat jet spray tip (Teejet $80.02 \mathrm{E}$ ), calibrated at $0.50 \mathrm{~m}$ height above the target surface, and with a relative volume of 200 $\mathrm{L} \mathrm{ha}^{-1}$. After herbicide application, pots were placed in the greenhouse and irrigated on the following day to secure adequate foliar absorption of the molecules.

Trials were set up in randomized block design $(n=4)$, factorial scheme with six biotypes and eight rates of the herbicide chlorimuron-ethyl (sulfonylurea), and five biotypes and eight rates of the herbicide imazethapyr (imidazolinone). Sufficient seeds did not allow biotype 3 to receive applications of imazethapyr. Rates applied were multiple values of the recommended rate $(\mathrm{R})$ for each herbicide $(0.0 \mathrm{R} ; 0.06 \mathrm{R}$; $0.125 \mathrm{R} ; 0.5 \mathrm{R} ; 1 \mathrm{R} ; 2 \mathrm{R}$; 4R and $16 \mathrm{R})$. The recommended rate adopted was $17.5 \mathrm{~g} \mathrm{ha}^{-1}$ for chlorimuronethyl, and $100.0 \mathrm{~g} \mathrm{ha}^{-1}$ for imazethapyr. Herbicide treatments are listed in Table 2; all treatments received the addition of mineral oil at $0.5 \% \mathrm{v} / \mathrm{v}$ concentration.

Evaluation - Percent control and percent fresh weight were evaluated at 28 days after the application (DAA). Percent control was rated as $0 \%$ when the herbicide effect was absent, and $100 \%$ when all plants

Table 1 - Number, suspect, species, and origin locality of Bidens biotypes (B. pilosa and B. subalternans).

\begin{tabular}{|c|c|c|c|c|c|}
\hline \multirow{2}{*}{$\mathrm{N}^{\circ} 1$} & \multirow{2}{*}{ Biotype $^{2}$} & \multirow{2}{*}{ Species } & \multicolumn{3}{|c|}{ Locality } \\
\hline & & & State & City & Latitude / Longitude \\
\hline 1 & Resistant & Bidens subalternans & Mato Grosso & Rondonópolis & $16^{\circ} 22^{\prime} 30^{\prime \prime} \mathrm{S} / 54^{\circ} 37^{\prime} 30^{\prime \prime} \mathrm{W}$ \\
\hline 2 & Resistant & Bidens subalternans & São Paulo & Presidente Prudente & $22^{\circ} 11^{\prime} 15^{\prime \prime} \mathrm{S} / 51^{\circ} 26^{\prime} 15^{\prime \prime} \mathrm{W}$ \\
\hline 3 & Resistant & Bidens subalternans & Mato Grosso do Sul & São Gabriel do Oeste & $19^{\circ} 26^{\prime} 15^{\prime \prime} \mathrm{S} / 54^{\circ} 33^{\prime} 45^{\prime \prime} \mathrm{W}$ \\
\hline 4 & Resistant & Bidens pilosa & Paraná & Castro & $24^{\circ} 48^{\prime} 45^{\prime \prime} \mathrm{S} / 50^{\circ} 03^{\prime} 45^{\prime \prime} \mathrm{W}$ \\
\hline 5 & Susceptible & Bidens subalternans & São Paulo & Santa Bárbara do Oeste & $22^{\circ} 48^{\prime} 45^{\prime \prime} \mathrm{S} / 47^{\circ} 26^{\prime} 15^{\prime \prime} \mathrm{W}$ \\
\hline 6 & Susceptible & Bidens pilosa & São Paulo & Piracicaba & $22^{\circ} 41^{\prime} 15^{\prime \prime} \mathrm{S} / 47^{\circ} 41^{\prime} 15^{\prime \prime} \mathrm{W}$ \\
\hline
\end{tabular}

${ }^{1} \mathrm{~N}^{\mathrm{o}}$ - number; ${ }^{2}$ Suspect ALS resistant or susceptible biotype. 
Table 2 - Treatments with multiples of the recommended rates of the herbicides applied on Bidens pilosa and B. subalternans biotypes.

\begin{tabular}{|c|c|c|c|c|c|c|c|c|}
\hline \multirow{2}{*}{ Treatments } & \multicolumn{8}{|c|}{ Multiples of the recommended rate (R) } \\
\hline & OR & $0.06 \mathrm{R}$ & $0.125 \mathrm{R}$ & $0.5 \mathrm{R}$ & $1.0 \mathrm{R}^{*}$ & $2.0 \mathrm{R}$ & $4.0 \mathrm{R}$ & $16.0 \mathrm{R}$ \\
\hline Herbicides & \multicolumn{8}{|c|}{ Rate $\left(\mathrm{g} \mathrm{ha}^{-1}\right)$} \\
\hline chlorimuron-ethyl & 0.0 & 1.09 & 2.19 & 8.75 & 17.50 & 35.00 & 70.00 & 280.00 \\
\hline imazethapyr & 0.0 & 6.25 & 12.50 & 50.00 & 100.00 & 200.00 & 400.00 & 1600.00 \\
\hline
\end{tabular}

$* \mathrm{R}$ is the recommended rate to each herbicide.

died. Percent fresh weight was obtained based on the pots that received the application rate $0 \mathrm{D}$ (check), as $100 \%$ of possible weight. Fresh weights were corrected based on the checks within each respective block. Percent correction was used to make up for differences in biotypes growth rates.

Data analysis and elaboration of dose-response curves - Data were initially submitted to ANOVA ("F" test). Treatment showing significant, qualitative effects (biotypes), were compared by the application of Tukey's test $(\alpha=0.05)$; quantitative effects (rates), were adjusted to a log-logistic model, proposed by Seefeldt et al. (1995),

$$
y=a+\frac{b}{\left[1+\left(\frac{x}{c}\right)^{d}\right]}
$$

where: $y$ is the variable, $x$ is the herbicide rate ( $\mathrm{g}$ i.a. $\mathrm{ha}^{-1}$ ); and $a, b, c$ and $d$ are parameters of the curve, that $a$ is the minimum limit of the curve, $b$ is the difference among the maximum and minimum point of the curve, $c$ is the rate that promotes $50 \%$ of response from the variable and $d$ is the curve slope around $c$.

The log-logistic model presents an advantage once one of the parameters of the equation $(c)$ is an estimative of $\mathrm{C}_{50}$ or $\mathrm{GR}_{50}$ value (Christoffoleti, 2002). $\mathrm{C}_{50}$ (control by $50 \%$ ) or $\mathrm{GR}_{50}$ (growth reduction by $50 \%$ ) are the herbicide rate $\left(\mathrm{g}\right.$ i.a. $\left.\mathrm{ha}^{-1}\right)$ that promotes $50 \%$ of control or weight reduction on plants, respectively (Christoffoleti, 2002; Christoffoleti \& LópezOvejero, 2004). From the equations obtained it was also possible to re-calculate mathematically the values of $\mathrm{C}_{50}$ or $\mathrm{GR}_{50}$, which were considered during the discussion (Carvalho et al., 2005). Using the $\mathrm{C}_{50}$ or $\mathrm{GR}_{50}$ values, the resistance factor was obtained to all biotypes and all herbicides tested. The resistance factor $\left(\mathrm{C}_{50}\right.$ resistant / $\mathrm{C}_{50}$ susceptible; $\mathrm{GR}_{50}$ resistant / $\mathrm{GR}_{50}$ susceptible or simply $\mathrm{R} / \mathrm{S}$ ) is an adimensional number that expresses how many times the necessary rate to control $50 \%$ of resistant biotype is superior than the rate that controls $50 \%$ of susceptible biotype, of the same species (Christoffoleti, 2002; Hall et al., 1998).

\section{RESULTS AND DISCUSSION}

Bidens pilosa and B. subalternans show morphological differences mainly in the cypselas: in Bidens pilosa the majority of cypselas have three awns, while in B. subalternans they have four. The angle between the awns and the cypsela is about $135^{\circ}$ in $B$. pilosa, while in $B$. subalternans the angle is about $180^{\circ}$. In B. pilosa, the fruit surface is scabrous and minutely tuberculate in almost all its length, with trichomes arising from the tubercles. In B. subalternans, the surface of the cypselas is scabrous, lacks tubercles and has trichomes concentrated in the apex. Both species are widely distributed in agricultural areas and along roadsides.

According to Kissmann \& Groth (1999), $B$. pilosa and $B$. subalternans are sympathric, soybean crop pests. However, in this research, we identified by morphological seed and seedling characters, all resistant seeds from Paraná as B. pilosa, and all resistant seeds from Mato Grosso, Mato Grosso do Sul and São Paulo as $B$. subalternans.

For both herbicides, in all evaluations, there were significant interactions between the rates applied and Bidens biotypes, justifying factorial decomposition. Table 3 presents the parameters of log-logistic model of two variables studied for the herbicides chlorimuron-ethyl and imazethapyr. These parameters allowed fitting plant control or fresh weight (\%) as function of herbicides rates, as presented on Figures 1 to 4. Least significant differences (LSD) of Tukey's test $(\alpha=0.05)$ comparing biotypes, also are presented in the figures.

Control results indicated that the $B$. subalternans susceptible biotype is more tolerant than the $B$. pilosa susceptible biotype, and that $B$. subalternans resistant biotypes display higher level of resistance than $B$. pilos a resistant biotypes. Neither chlorimuron-ethyl nor imazethapyr was effective in controlling resistant biotypes of $B$. pilos $a$ and $B$. subalternans (Figures 1 and 2). However, both herbicides were effective in controlling the susceptible biotypes of $B$. pilosa and $B$. subalternans at recommended rates. $\mathrm{C}_{50}$ and $\mathrm{GR}_{50}$ values showed differences between 
Table 3 - Log logistic model ${ }^{1}$ parameters to Bidens biotypes for all variables evaluated, when treated with chlorimuronethyl or imazethapyr.

\begin{tabular}{|c|c|c|c|c|c|c|c|c|}
\hline \multirow{2}{*}{$\mathrm{N}^{\mathrm{o}}$} & \multirow{2}{*}{ State } & \multirow{2}{*}{ Species } & \multirow{2}{*}{ Variable } & \multicolumn{5}{|c|}{ Parameters } \\
\hline & & & & $\mathrm{a}$ & $\mathrm{b}$ & $\mathrm{c}$ & $\mathrm{d}$ & $\mathrm{R}^{2}$ \\
\hline \multicolumn{9}{|c|}{ chlorimuron-ethyl } \\
\hline \multirow[t]{2}{*}{1} & MT & B. subalternans & Control $\%-28$ DAA & -1.249 & 93.427 & 234.410 & -1.971 & 0.980 \\
\hline & & & Fresh weight (\%) & 7.081 & 79.694 & 76.360 & 1.372 & 0.975 \\
\hline \multirow[t]{2}{*}{2} & SP & B. subalternans & Control $\%-28$ DAA & -2.067 & 85.697 & 87.220 & -0.979 & 0.972 \\
\hline & & & Fresh weight $(\%)$ & 11.209 & 81.950 & 69.211 & 0.591 & 0.859 \\
\hline \multirow[t]{2}{*}{3} & MS & B. subalternans & Control $\%-28$ DAA & -0.822 & 86.038 & 169.380 & -1.215 & 0.961 \\
\hline & & & Fresh weight $(\%)$ & 16.668 & 76.899 & 209.040 & 1.897 & 0.960 \\
\hline \multirow[t]{2}{*}{4} & PR & B. pilosa & Control $\%-28$ DAA & -0.556 & 102.410 & 75.066 & -1.752 & 0.983 \\
\hline & & & Fresh weight $(\%)$ & -1.638 & 99.543 & 46.461 & 1.489 & 0.970 \\
\hline \multirow[t]{2}{*}{5} & SP & B. subalternans & Control \% - 28 DAA & -0.646 & 102.932 & 5.695 & -1.225 & 0.998 \\
\hline & & & Fresh weight (\%) & -5.988 & 106.568 & 4.391 & 0.641 & 0.969 \\
\hline \multirow[t]{2}{*}{6} & SP & B. pilosa & Control $\%-28$ DAA & -0.431 & 103.964 & 3.654 & -0.952 & 0.991 \\
\hline & & & Fresh weight $(\%)$ & -0.027 & 102.246 & 1.454 & 0.988 & 0.950 \\
\hline \multicolumn{9}{|c|}{ imazethapyr } \\
\hline \multirow[t]{2}{*}{1} & MT & B. subalternans & Control $\%-28$ DAA & 2.035 & 106.650 & 73.585 & -0.476 & 0.964 \\
\hline & & & Fresh weight (\%) & -5.065 & 104.400 & 16.556 & 0.490 & 0.972 \\
\hline \multirow[t]{2}{*}{2} & SP & B. subalternans & Control \% - 28 DAA & -2.807 & 102.100 & 140.160 & -1.516 & 0.967 \\
\hline & & & Fresh weight (\%) & -5.808 & 100.910 & 124.410 & 0.641 & 0.964 \\
\hline \multirow[t]{2}{*}{4} & PR & B. pilosa & Control $\%-28$ DAA & 1.780 & 102.020 & 20.048 & -1.027 & 0.970 \\
\hline & & & Fresh weight (\%) & -0.307 & 100.570 & 7.739 & 1.260 & 0.993 \\
\hline \multirow[t]{2}{*}{5} & SP & B. subalternans & Control $\%-28$ DAA & 0.132 & 103.214 & 14.803 & -0.874 & 0.999 \\
\hline & & & Fresh weight (\%) & 0.263 & 101.303 & 6.926 & 0.834 & 0.956 \\
\hline \multirow[t]{2}{*}{6} & SP & B. pilosa & Control \% - 28 DAA & 0.175 & 102.298 & 10.101 & -0.900 & 0.998 \\
\hline & & & Fresh weight (\%) & 4.105 & 97.759 & 5.367 & 1.076 & 0.939 \\
\hline
\end{tabular}

${ }^{1}$ Model: $y=a+\left(b /\left(1+(x / c)^{d}\right)\right)$.

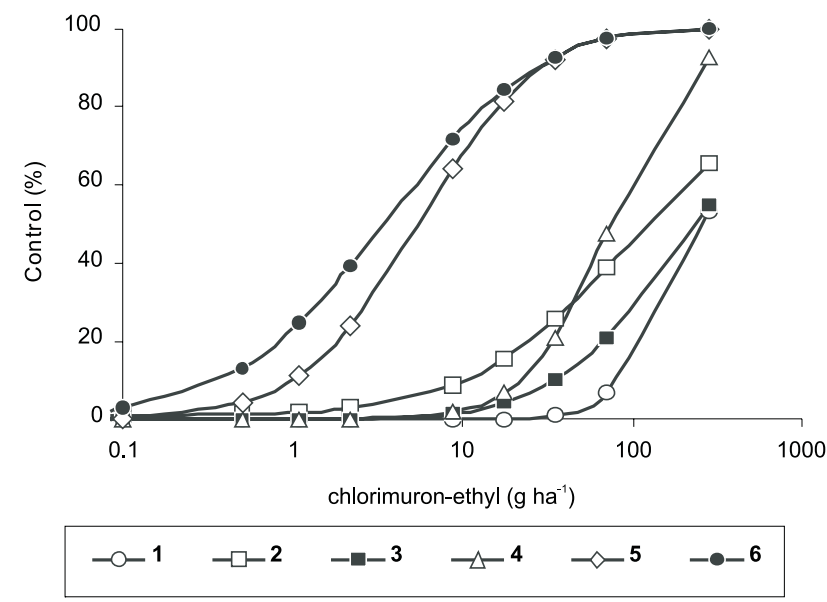

Figure 1 - Dose-response curves of resistant (R) and susceptible (S) biotypes of Bidens pilosa and B. subalternans for the herbicide chlorimuron-ethyl, at 28 DAA. 1 - $B$. subalternans $\mathrm{R}$ - MT; 2 - B. subalternans $\mathrm{R}$ - SP; 3 B. subalternans R - MS; 4 - B. pilosa R - PR; 5 - B. subalternans $\mathrm{S}-\mathrm{SP} ; 6-B$. pilosa $\mathrm{S}-\mathrm{SP}$. $\mathrm{LSD}_{\text {(biotypes) }}$ $=4.23$ at Tukey test $(\alpha=0.05)$.

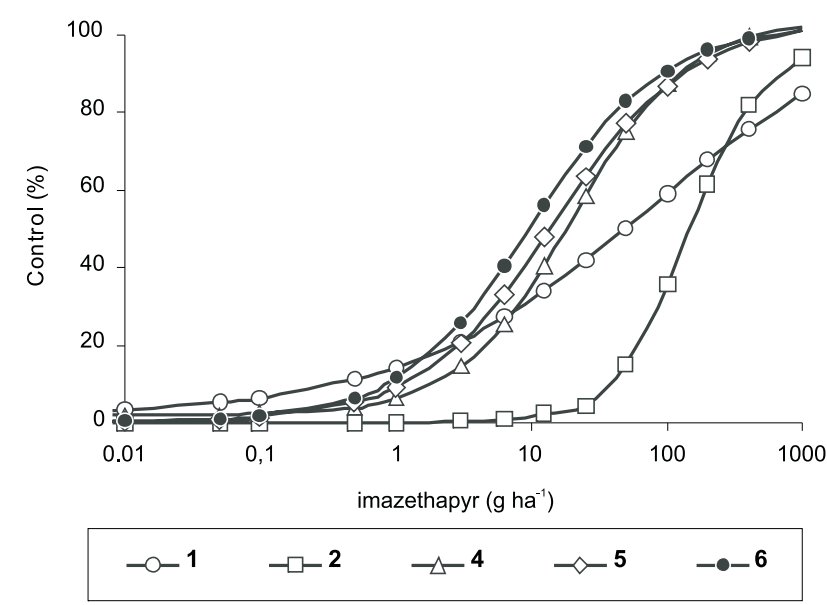

Figure 2 - Dose-response curves of resistant (R) and susceptible (S) biotypes of Bidens pilosa and B. subalternans for the herbicide imazathepyr, at 28 DAA. 1 - $B$. subalternans R - MT; 2 -B. subalternans R - SP; 4 - $B$. pilosa $\mathrm{R}$ - PR; 5 - B. subalternans $\mathrm{S}$ - SP; 6 - B. pilosa $\mathrm{S}-\mathrm{SP}$. $\operatorname{LSD}_{\text {(biotype) }}=3.54$ at Tukey Test $(\alpha=0.05)$. 
Table $4-\mathrm{C}_{50}, \mathrm{GR}_{50}$ and resistance factor $(\mathrm{R} / \mathrm{S})$ for resistant and susceptible biotypes of Bidens pilosa and B. subalternans.

\begin{tabular}{|c|c|c|c|c|c|c|}
\hline \multirow{3}{*}{$\mathrm{N}^{01}$} & \multirow{3}{*}{ State } & \multirow{3}{*}{ Species } & \multicolumn{4}{|c|}{$\mathrm{C}_{50}$ or $\mathrm{GR}_{50}$} \\
\hline & & & \multicolumn{2}{|c|}{ chlorimuron-ethyl } & \multicolumn{2}{|c|}{ imazethapyr } \\
\hline & & & Control & Fresh Weight & Control & Fresh weight \\
\hline \multicolumn{7}{|c|}{ - } \\
\hline 1 & MT & B. subalternans & 258.765 & 68.228 & 48.167 & 13.230 \\
\hline 2 & SP & B. subalternans & 136.309 & 82.906 & 146.664 & 89.225 \\
\hline 3 & MS & B. subalternans & 229.079 & 240.737 & -- & -- \\
\hline 4 & PR & B. pilosa & 73.989 & 44.178 & 18.022 & 7.733 \\
\hline 5 & SP & B. subalternans & 5.549 & 3.747 & 13.704 & 7.232 \\
\hline 6 & SP & B. pilosa & 3.432 & 1.518 & 9.536 & 6.013 \\
\hline \multicolumn{7}{|c|}{ Resistance factor $(\mathrm{R} / \mathrm{S})$} \\
\hline 1 & MT & B. subalternans & 46.63 & 18.21 & 3.51 & 1.83 \\
\hline 2 & SP & B. subalternans & 24.57 & 22.12 & 10.70 & 12.32 \\
\hline 3 & MS & B. subalternans & 41.28 & 64.24 & -- & -- \\
\hline 4 & PR & B. pilosa & 21.56 & 29.09 & 1.89 & 1.29 \\
\hline
\end{tabular}

${ }^{1} \mathrm{~N}^{\mathrm{o}}$ - Number.

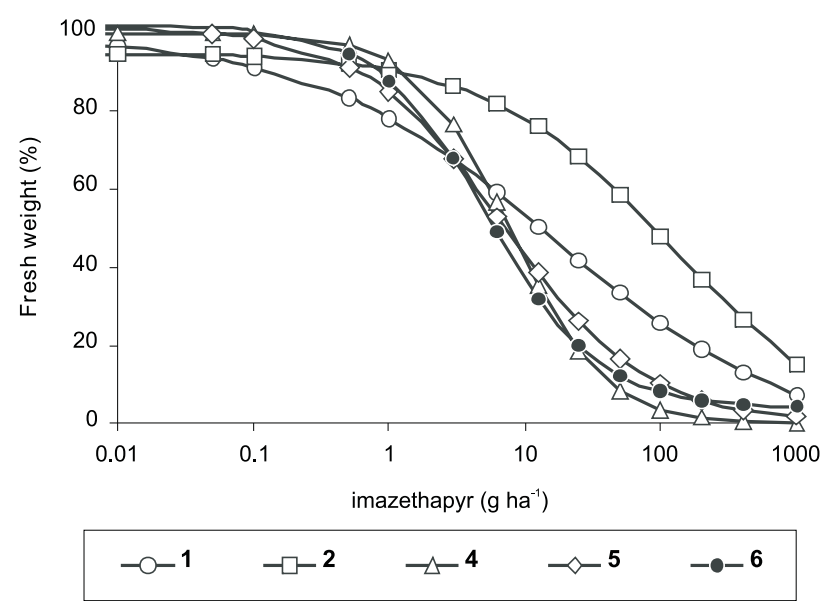

Figure 3 - Fresh weight (\%) of resistant (R) and susceptible (S) biotypes of Bidens pilosa and B. subalternans for the herbicide chlorimuron-ethyl, at 28 DAA. 1 - $B$. subalternans R - MT; 2 - B. subalternans R - SP; 3 B. subalternans R - MS; 4 - B. pilosa R - PR; 5 - B. subalternans $\mathrm{S}$ - SP; 6 - B. pilosa $\mathrm{S}$ - SP. $\mathrm{LSD}_{\text {(biotypes) }}=$ 32.76 at Tukey Test $(\alpha=0.05)$.

the resistant (R) and susceptible (S) biotypes of both species (Table 4). According to Kissmann \& Groth (1999), B. subalternans has higher levels of tolerance to herbicides than $B$. pilosa.

B. subalternans from Mato Grosso and Mato Grosso do Sul had highest levels of resistance to chlorimuron-ethyl. Rates up to $70 \mathrm{~g} \mathrm{ha}^{-1}$ of this herbicide were used to obtain controls of $50 \%$ in these populations. To reach control of $50 \%$ in B. pilosa population, rates of the same herbicide used were lower (Table 4). Control tests with imazethapyr showed that B. subalternans from São Paulo displayed highest lev-

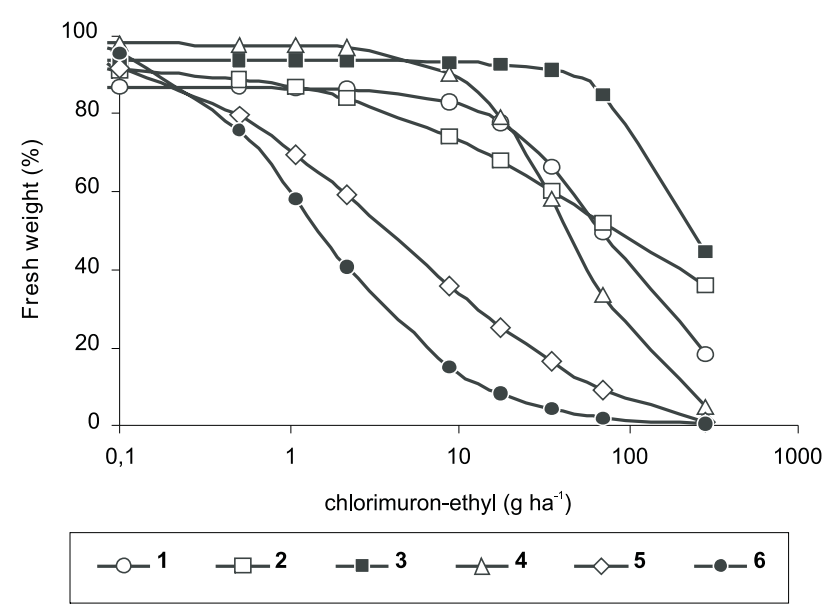

Figure 4 - Fresh weight (\%) of resistant (R) and susceptible (S) biotypes of Bidens pilosa and B. subalternans for the herbicide chlorimuron-ethyl, at 28 DAA. $1-B$. subalternans R - MT; 2 - B. subalternans R - SP; 4 B. pilosa $\mathrm{R}$ - PR; 5 - B. subalternans $\mathrm{S}$ - SP; 6 - B. pilosa $\mathrm{S}-\mathrm{SP}$. $\mathrm{LSD}_{\text {(biotypes) }}=29.66$ at Tukey Test $(\alpha=0.05)$.

els of resistance. Rates up to $140 \mathrm{~g} \mathrm{ha}^{-1}$ of the herbicide were used to obtain control of $50 \%$ in these populations (Table 4). These results are similar to those reported by Gelmini et al. (2002), but are in disagreement with Christoffoleti (2002) and Monquero et al. (2000), whose data showed that B. pilosa biotype presented higher levels of resistance to imazethapyr.

Cross-resistance between the two ALS-inhibiting herbicides (the imidazolinones - IMIs and the sulfonylurea - SUL) was registered for all B. pilosa and $B$. subalternans suspect biotypes studied. Both species had different degrees of cross-resistance to ALS-inhib- 
iting herbicides. These data agree with results of Christoffoleti (2002) and Monquero et al. (2003) for $B$. pilosa, and Gelmini et al. (2002) for $B$. subalternans.

There was percent fresh weight reduction with increasing herbicides rates (Figures 3 and 4). Once again, on the supposed resistant biotypes, the rates needed to reduce fresh weight were greater in comparison to the susceptible biotypes. For this variable, the $B$. subalternans biotype from Mato Grosso do Sul was the least sensitive to the herbicide chlorimuron-ethyl (Figure 3), while B. subalternans biotype from São Paulo was the least sensitive to the herbicide imazethapyr (Figure 4).

Resistance in many weeds has been attributed to single point mutations, which can occur at multiple sites in the ALS gene (Tan \& Medd, 2002). Base changes in at least four protein domains have been associated with in vivo resistance in field plants (Wright et al., 1998). The most common mutation in biotypes selected by sulfonylureas is in the highly conserved Domain A, that codes for 13 amino acids, where any alteration of the codon for Pro confers resistance, primarily, to sulfonylureas (SUL) and triazolopyrimidines (TP) (Guttieri et al., 1992). A Trp $\rightarrow$ Leu mutation in Domain B has been associated with broad cross-resistance to representatives of all four families of ALSinhibiting chemicals (Bernasconi et al., 1995; Woodworth et al., 1996a). In Domain C, an Ala $\rightarrow$ Thr mutation appears to confer resistance only to imidazolinones (IMI) (Bernasconi et al., 1995), whilst an Ala $\rightarrow$ Val substitution in Domain D is reported to confer broad cross-resistance (Woodworth et al., 1996b), as in the case of the mutation in Domain B.

Many mutations have been documented for ALS, confering different resistance levels to various classes of inhibitors; resistant biotypes to ALS inhibiting herbicides show cross-resistance to members of chemical families with the same action mechanism (Tranel \& Wright, 2002). Many works have shown that ALS-resistant weed biotypes have cross-resistance to herbicides that belong to chemical group that selected them, and diverse levels of cross-resistance to other herbicide groups with the same action mechanism (Rizzardi et al., 2002). It is probably a consequence of the selection pressure imposed by the main herbicide used, which selected those mutations especially related with its chemical group. This can, at least in part, explain results of this work and the great diversity of results reported in the literature. There are many ALS amino acid substitutions that confer herbicide resistance (Tranel \& Wright, 2002); however we did not find any papers that reported data for the B. pilosa-B. subalternans complex.
The majority of the resistance cases of hairy beggarticks to ALS-inhibiting herbicides occur in Bidens subalternans, not in B. pilosa, as previously thought. The confirmation that susceptible biotypes of $B$. subaternans are more tolerant to these herbicides than $B$. pilosa reveals how important species identification is to effective control. The identification of point mutations in the ALS gene domains can clarify the resistance patterns and give insights on the necessity of alternative systems that prevent or delay the emergence of resistance.

\section{ACKNOWLEDGEMENTS}

The authors would like to thank HRAC-Brazil to support this work.

\section{REFERENCES}

BERNASCONI, P.; WOODWORTH, A.R.; ROSEN, B.A.; SUBRAMANIAN, M.V.; SIEHL, D.L. A naturally occurring point mutation confers broad range tolerance to herbicides that target acetolactate synthase. Journal of Biological Chemistry, v.270, p.17381-17385, 1995.

CARVALHO, S.J.P.; LÓPEZ-OVEJERO, R.F.; MOYSÉS, T.C.; CHAMMA, H.M.C.P.; CHRISTOFFOLETI, P.J. Identificação de biótipos de Bidens spp. resistentes aos inibidores da ALS através de teste germinativo. Planta Daninha, v.22, p.411-417, 2004.

CARVALHO, S.J.P.; LOMBARDI, B.P.; NICOLAI, M.; LÓPEZOVEJERO, R.F.; CHRISTOFFOLETI, P.J. Curvas de dose-resposta para avaliação do controle de fluxos de emergência de plantas daninhas pelo herbicida imazapic. Planta Daninha, v.23, p.535-542, 2005.

CHRISTOFFOLETI, P.J. Curvas de dose-resposta de biótipos resistente e suscetível de Bidens pilosa L. aos herbicidas inibidores da ALS. Scientia Agricola, v.59, p.513-519, 2002.

CHRISTOFFOLETI, P.J.; LÓPEZ-OVEJERO, R.F. Definições e situação da resistência de plantas daninhas aos herbicidas no Brasil e no Mundo. In: CHRistoffoleti, P.J. (Coord.) Aspectos da resistência de plantas daninhas a herbicidas. 2.ed. Campinas: Associação Brasileira de Ação a Resistência de Plantas aos Herbicidas (HRAC-BR), 2004. p.3-22.

GELMINI, G.A.; VICTÓRIA FILHO, R.; NOVO, M.C.S.S.; ADORYAN, M.L. Resistência de Bidens subalternans aos herbicidas inibidores da enzima acetolactato sintase utilizados na cultura da soja. Planta Daninha, v.20, p.319-325, 2002.

GROMBONE-GUARATINI, M.T.; SOLFERINI, V.N.; SEMIR, J. Reproductive biology in species of Bidens L. (Asteraceae). Scientia Agricola, v.61, p.185-189, 2004.

GROMBONE-GUARATINI, M.T.; BRANDAO-SILVA, K.L.; SOLFERINI, V.N.; SEMIR, J.; TRIGO, J.R. Sesquiterpene and polyacetylene profile of the Bidens pilosa complex (Asteraceae: Heliantheae) from southeast Brazil. Biochemical Systematics and Ecology, v.33, p.479-483, 2005a.

GROMBONE-GUARATINI, M.T.; SEMIR, J.; SOLFERINI, V.N. Low allozimic variation in the Bidens pilosa L. complex (Asteraceae). Biochemical Genetics, v.43, p.335-345, 2005 b.

GUTTIERI, M.J.; EBERLEIN, C.V.; MALLORY-SMITH, C.A.; THILL, D.C.; HOFFMAN, D.L. DNA sequence variation in domain A of the acetolactate synthase genes of herbicide resistant and susceptible weed biotypes. Weed Science, v.40, p.670-676, 1992.

HALL, L.M.; STROME, K.M.; HORSMAN, G.P. Resistance to acetolactate synthase inhibitors and quinclorac in a biotype of false clover (Gallium spurium). Weed Science, v.46, p.390-396, 1998. 
HEAP, I. The international survey of herbicide resistant weeds. Available in: http://www.weedscience.org/in.asp. Accessed at: Oct. 20, 2005.

KISSMANN, K.G.; GROTH, D. Plantas infestantes e nocivas. 2.ed. v.2. São Paulo: BASF, 1999. 978p.

MONQUERO, P.A.; CHRISTOFFOLETI, P.J.; DIAS, C.T.S. Resistência de plantas daninhas aos herbicidas inibidores da ALS na cultura da soja (Glycine max). Planta Daninha, v.18, p.419-425, 2000.

MONQUERO, P.A.; CHRISTOFFOLETI, P.J.; CARRER, H. Biology, management and biochemical/genet characterization of weed biotypes resistant to acetolactate synthase inhibitor herbicides. Scientia Agricola, v.60, p.495-503, 2003.

RIZZARDI, M.A.; VIDAL, R.A.; FLECK, N.G.; AGOSTINETTO, D. Resistência de plantas aos herbicidas inibidores da acetolactato sintase. Planta Daninha, v.20, p.149-158, 2002.

SEEFELDT, S.S.; JENSEN, J.E.; FUERST, E.P. Log-logistic analysis of herbicide dose-response relationship. Weed Technology, v.9, p.218-227, 1995.

TAN, M.K.; MEDD, R.W. Characterization of the acetolactate synthase (ALS) gene of Raphanus raphanistrum L. and the molecular assay of mutation associated with herbicide resistance. Plant Science, v.163, p.195-205, 2002.
TRANEL, P.J.; WRIGHT, T.R. Resistance of weeds to ALS-inhibiting herbicides: what have we learned? Weed Science, v.50, p.700-712, 2002.

WOODWORTH, A.R.; BERNASCONI, P.; SUBRAMANIAN, M.; ROSEN, B. A second naturally occurring point mutation confers broad-based tolerance to acetolactate synthase inhibitors. Plant Physiology, v.111, p.S105, 1996a.

WOODWORTH, A.R.; ROSEN, B.A.; BERNASCONI, P. Broad range resistance to herbicides targeting acetolactate synthase (ALS) in a field isolate of Amaranthus sp. is conferred by a Trp to Leu mutation in the ALS gene. Plant Physiology, v.111, p.1353, 1996b.

WRIGHT, T.R.; BASCOMB, N.F.; STURNER, S.F.; PENNER, D. Biochemical mechanism and molecular basis for ALS-inhibiting herbicide resistance in sugarbeet (Beta vulgaris) somatic cell selections. Weed Science, v.46, p.13-23, 1998.

Received November 01, 2005

Accepted March 10, 2006 